\title{
Effects of Sea Water Physical Condition on a Population of the Clam Ruditapes philippinarum
}

\author{
柿野 純* \\ 千葉県内水面水産研究センター。广 285-0866 千葉県佐倉市臼井台 1390 \\ Jun KAKINO* \\ Chiba Prefectural Fresh Water Fisheries Research Center. Usuidai 1390, Sakura City, Chiba Prefecture 285-0866, Japan
}

\begin{abstract}
Physical conditions of sea water strongly influence growth and survival of the clam Ruditapes philippinarum; however, quantitative analysis of this influence has not been fully made. In this paper, effects of some physical condition (vorticity, tidal current, and waves) on population characteristics of the clam (recruitment, growth, and passive emigration) on the tidal flat and shoal of Banzu, Tokyo Bay, are reported. The vorticity (an indicator of shear, such as that caused by tidal fronts or vortices) tended to be larger offshore. Abundant recruits $(<1 \mathrm{~mm}$ in shell length) were observed on offshore shoals. A positive correlation was observed between vorticity during the spring ebb tide and density of clam recruits. This suggests that planktonic larvae of the clam were transported onto the tidal flat during the flood tide, then settled on shoal bottoms where a large shear was induced during the ebb tide. A higher condition factor value and lower sharpness index were observed in clams on bottoms where the tidal current velocity was higher, suggesting that current velocity positively affects growth of the clam. During winter, most monitored clams seeded on the bottom (about $28 \mathrm{~mm}$ in shell length) were found to have emigrated under the strongest wave condition, which was associated with sediment erosion. Hydraulic model test indicates that the presence of laver culture nets decreases wave action. During the last two decades, the number of rows of laver culture structures on the lowest part of the tidal flat has decreased. This may lead to a decline in clam population during winter, due to a decreased capacity for wave buffering.
\end{abstract}

Key Words: clam growth, condition factor, current velocity, laver culture net, Ruditapes philippinarum, sharpness index, Shields parameter, vorticity

\section{はじめに}

アサリRuditapes philippinarum の生息に流れや波浪など の物理環境因子が, 浮遊幼生の輸送や海底砂の流動に伴う アサリの移動など，多くの面で影響を与えていることが指 摘されてきた。これらの近年までの知見の概要は, 増殖場 造成計画指針一ヒラメ・アサリ編一（増殖場造成計画指針 編集委員会 1997）にまとめられている.しかし, 現在も定 量的論議をするための知見が十分に集積されているとは言 い難い。ここでは，東京湾の盤洲干潟 (Fig. 1) において， 現地観測および数值計算や水理模型実験から求めた流れや 波浪などの物理環境因子とアサリの生息状況に関する諸要

Received 20 Dec. 2001 Accepted 11 Apr. 2002

*: Present Address: Chiba Prefectural Fisheries Research Center, Futtsu Laboratory. 3091 Kokubo, Futtsu, Chiba 266-0037, Japan. 千葉県水産研究セン夕一富津研究所. 干 266-0037 千葉県富津市小久保 3091 .
素として，1) 初期稚貝の密度，2) 貝の成長，3) 移動によ るアサリ密度の減少, との関係について, 解析した結果の 概要を紹介する。

盤洲干潟は, 東京湾の千葉県木更津市地先に位置し, 東 京湾に現存する干潟では最も面積が広い。潮間帯の岸沖方 向の距離は小檟川河口周辺に位置する久津間地先が最も長 く約 $1,700 \mathrm{~m}$, 金田漁業協同組合管内の中島地先が最も短 く約 $900 \mathrm{~m}$ である。底質は干潟岸側の一部にシルト，粘土 分の多い場所もあるが，概ね中央粒径 $200 \mu \mathrm{m}$ 程度の砂質 である、金田，牛込地先では干潟の沖側に砂堆が形成され ている。一方, 久津間から木更津の地先では蒙染漣が形成さ れている。現在 7 漁業協同組合があり，秋〜冬期にのり養 殖，春〜秋期にアサリ漁業が営まれている.

\section{流れの特性と初期稚貝との関係}

アサリ幼生は, 孵化後 2〜3 週間のプランクトン生活を経 て着底する（増殖場造成計画指針編集委員会 1997）。一般 に二枚貝浮遊幼生の遊泳速度（例えば, Cragg 1980）より も海水の水平方向の流速の方が速いために，浮遊幼生は鉛 


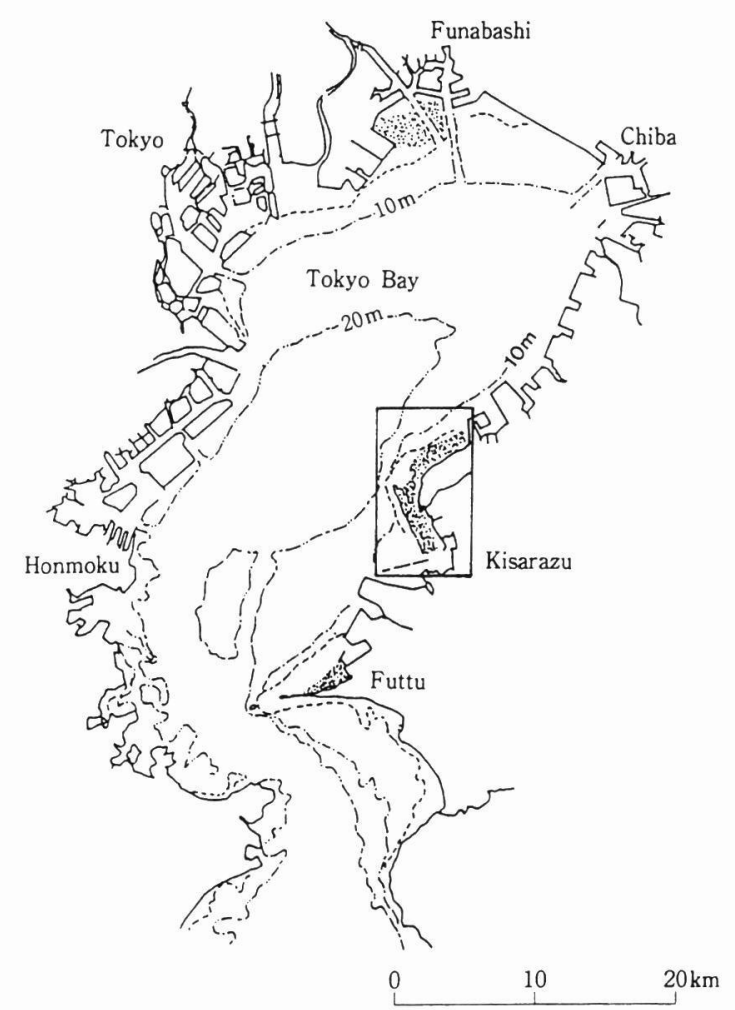

Fig. 1. Tokyo Bay, showing culture grounds (dotted areas) of the clam, Ruditapes philippinarum in coastal areas of Chiba Prefecture. A rectangle indicates the study site.

直方向の遊泳層の選択は可能であろうが, 水平方向の移送 は流れの特性に左右される。ここでは, 浮遊幼生の滞留や 集積を促進すると想定される地形性の渦や潮境など（杜多 1991) の指標として，数值計算で得られた大潮の上げ潮掞 よび下げ潮最強時の流れから算出した瀜度 (vorticity) と着 底後の経過時間が短い初期稚具 (款長 $1 \mathrm{~mm}$ 未満) の密度 との関倸を調べた（柿野ら 1991a; 鳥羽・柿野 1992; 柿野 1998).

な挹，渦度については，流体の速度成分をvとするとき， $\omega=\operatorname{rot} v$ が渦度と定義される。ここでは, 渦度の水平成分 を扱っており，

Vorticity $(1 /$ hour $)=|\partial v / \partial x-\partial u / \partial y| \quad u, v$ は流速の $x, y$ 成分

で定義される．渦や潮境のように隣接地点に向きや速さの 異なる流れが出現し，速度のシアー（流れのずれや歪みを 意味し, $x$ 軸方向の流速を $u, y$ 軸方向の流速を $v$ とすると き, $x$ 軸のシアーは $\partial u / \partial y, y$ 軸のシアーは $\partial v / \partial x)$ が大きい ほど, 渦度の值も大きくなることを利用している。

滑度の分布をFig. 2 に示す。上げ潮，下壮潮ともに小櫃 川河口周辺では河川水の影響によって值が大きくなってい る。 小檟川河口周辺を除くと, 上げ潮時には瓜倉から中島 にかけた区域や牛込の岸側に高い值となる領域がみられる が, 下げ潮時には沖合の方が高い値となる。一方, 1985 年 および 1986 年の 7 月に調べられたアサリ初期稚貝（殼長 1 $\mathrm{mm}$ 末満）の密度分布を Fig. 3 に示す。図中には同時に調 ベたバカガイ科二枚貝（図中にはバカガイとして表示）の 初期稚貝の密度分布も参考までに示した。両者の着底まで の挙動はほほ同様と考えられるので, 密度分布も同様の傾 向を示し, 初期稚貝は潮間带よりも潮下带の方が密度が高 い傾向にある。前記の上げ潮扮よび下げ潮時の渦度とアサ リ初期稚貝密度との関係を Fig. 4 に示す。ここでは, 渦度 および初期稚貝密度ともに数值の幅が大きいので, 対数表 示してある。両者の関係をみると，河川（小櫃川）の影響 域を除いて, 下げ潮時の渦度と初期稚貝の密度との間に正 の相関関係 $(r>0.7)$ がみられるが, 上げ潮時の渦度との間 には関係がみられなかった。これらのことから，沖合に分 布するアサリ浮遊幼生は，上げ潮によって潮間带に運ばれ た後，下げ潮時に潮境などシアーの大きい場所により多く 着底していると考えられる。

\section{流速とアサリの成長との関係}

アサリの成長速度は, 流れの速い場所の方が流れの遅い 場所よりも速いことが漁業者等の中では経験的に知られて いる，流速とアサリの成長との関係を調べるに当たって， アサリの成長（殼長や重量の増加）を漁場で詳細に把握す ることは困難なので, 肥满度 (condition factor) および丸形 指数 (sharpness index)（柿野 1988）と流速の関係を調べた (西沢ら 1992; 杮野 1996a).

肥満度は，アサリの成長期 (春〜秋季) にアサリの日間 成長率と高い相関関倸（西沢ら 1992）を持ち,

$$
\begin{aligned}
\text { 肥満度 }= & \text { 軟体部湿重量 }(\mathrm{g}) / \text { 微長 }(\mathrm{cm}) \times \text { 殼高 }(\mathrm{cm}) \\
& \times \text { 殼幅 }(\mathrm{cm}) \mid \times 100
\end{aligned}
$$

で計算される. 丸形指数は殼形とも呼ばれ，

$$
\text { 丸形指数 }=\text { 殼幅 }(\mathrm{cm}) / \text { 殼長 }(\mathrm{cm})
$$

で定義される。アサリの成育に適していない場所では，ア サリ款は丸みを带び, 丸形指数が高くなることが既に知ら れている(崔・大島 1958; 井上・山田 1954; 西沢ら 1992).

数值計算によって求めた大潮の上げ潮掞よび下げ潮最強 時の平均流速の分布を Fig. 5 に示す。流速は $4 \sim 12 \mathrm{~cm} / \mathrm{s}$ の 範囲であり，沖合ほど速くなる。

盤洲干潟で 1984 年および 1985 年の 5 月および 10 月の 計 4 回測定した殼長約 $30 \mathrm{~mm}$ のアサリの肥満度について, 各調査回ごとに平均值を計算し, 調查点每に平均值を上 回った頻度 (回数) を求め, その分布をFig. 6 に，また， 同時に測定された丸形指数の 4 回の平均值の分布を Fig. 7 に示す。肥満度が平均值を上回った頻度で解析した理由 は，調查した季節によって肥満度の值が大きく異なるので, 各調查点の数值を全季節一括して比較することができない ためである。

肥満度, 丸形指数ともに, 詳細にみると盤洲の鼻と呼ば れる盤洲干潟中央部でやや異なった分布を示すが, これ以 


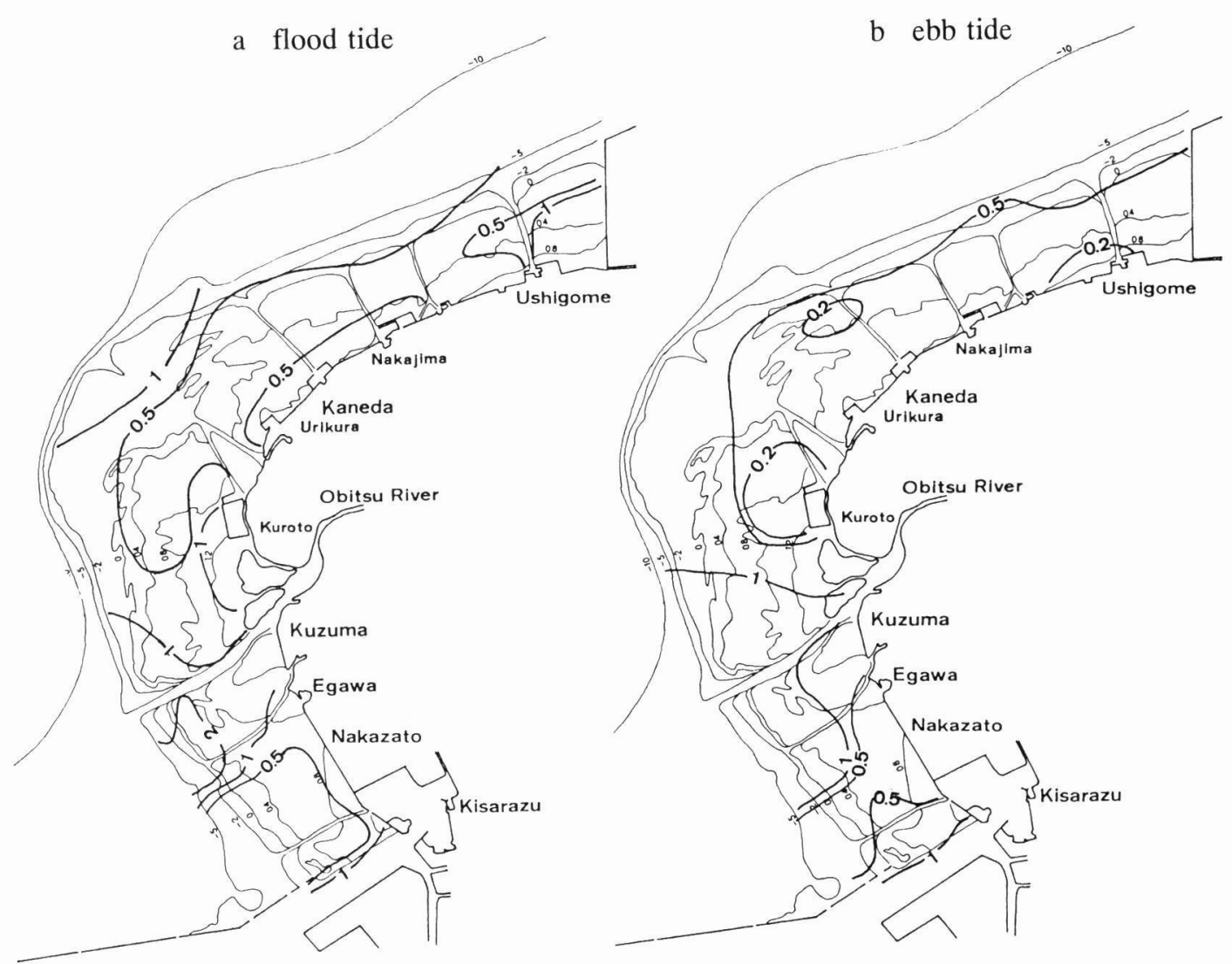

Fig. 2. Estimated distribution of vorticity $\left(\mathrm{hr}^{-1}\right.$ ) during spring tide (Kakino 1998). a, flood tide; b, ebb tide. Bottom depths are shown as elevation (m) from A. P.

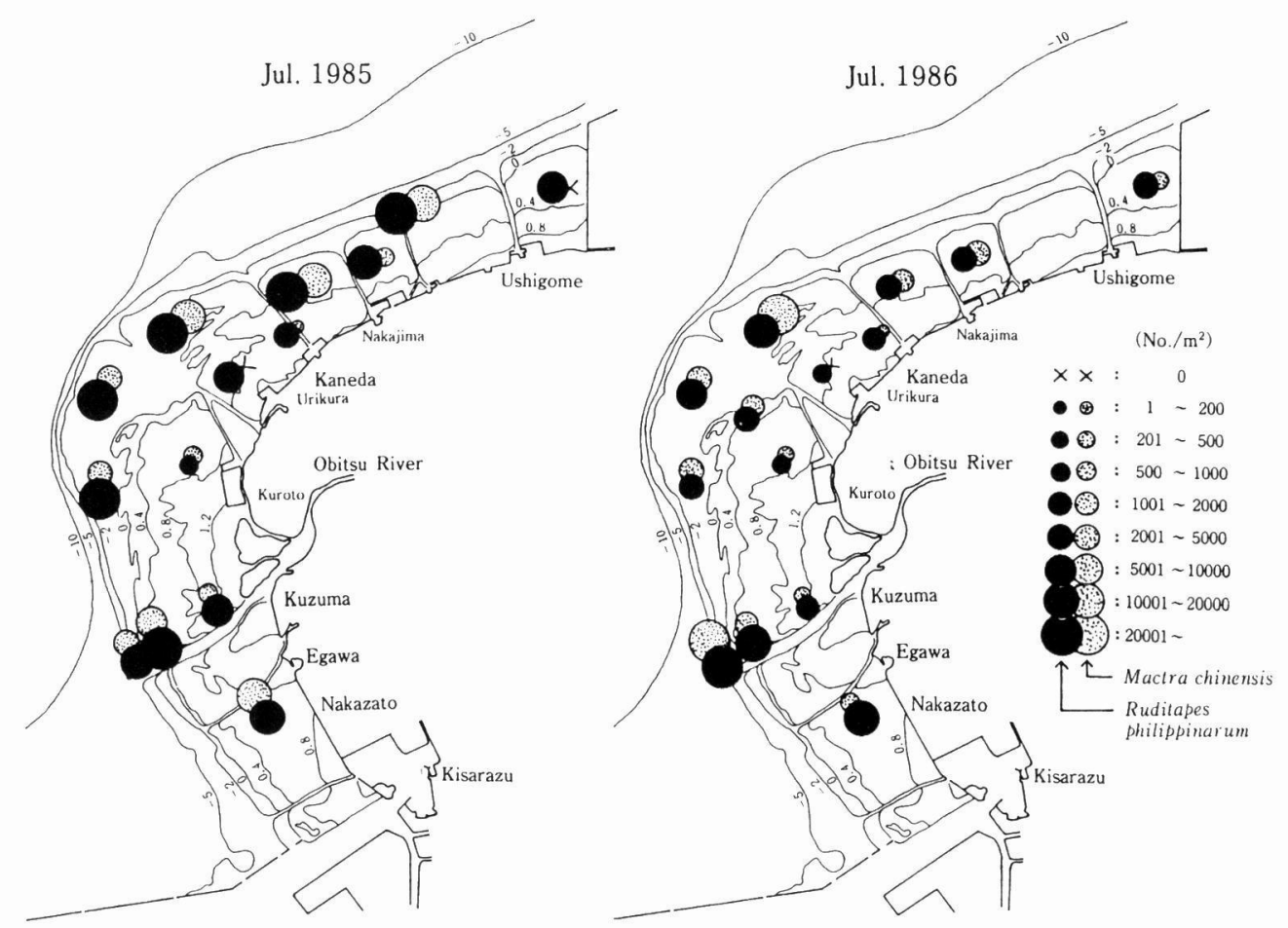

Fig. 3. Distribution of juveniles of Ruditapes philippinarum and Mactra chinensis ( $<1 \mathrm{~mm}$ in shell length) (Kakino et al. $1991 \mathrm{a})$. 


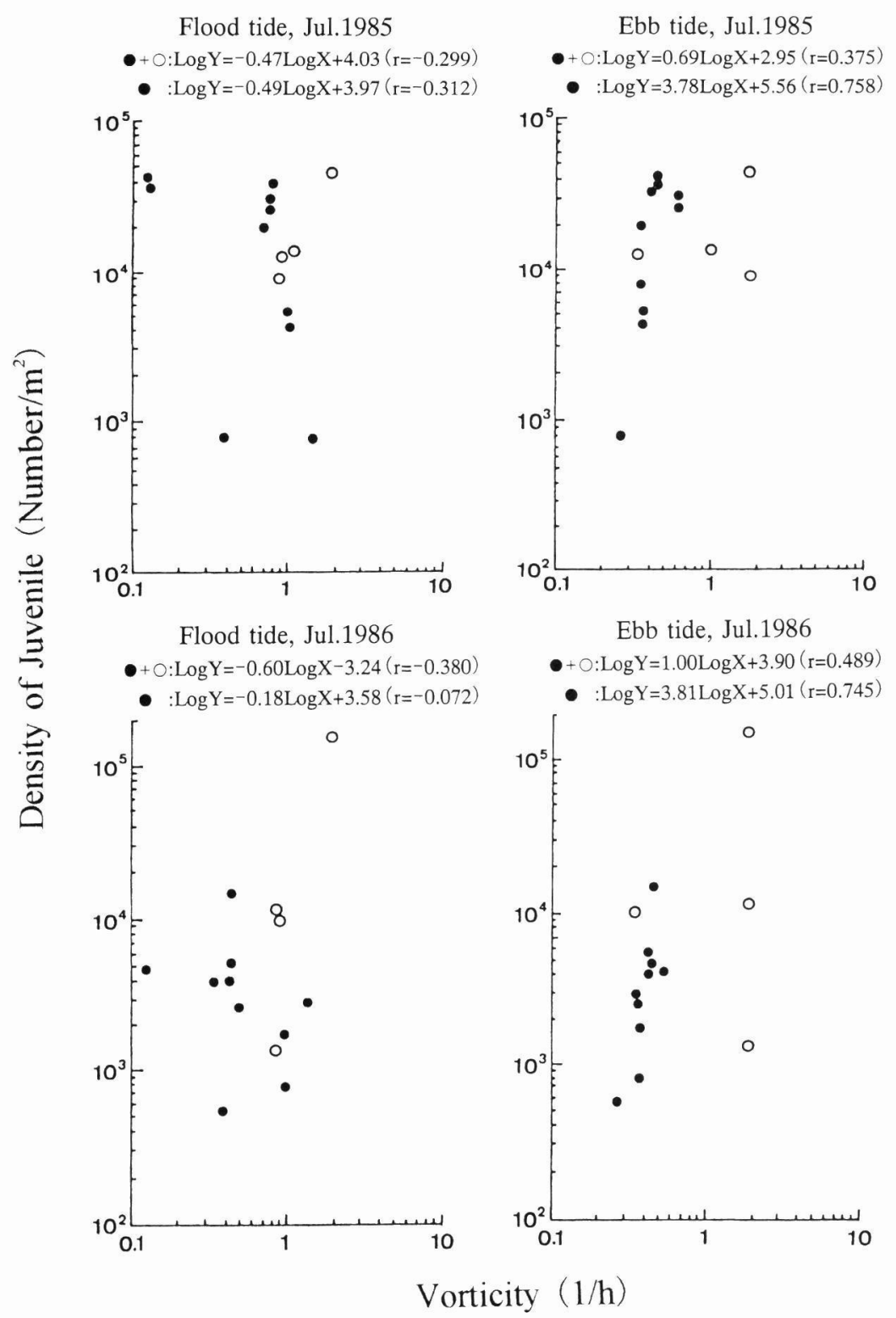

Fig. 4. Relationships between vorticity and density of juvenile Ruditapes philippinarum ( $<1 \mathrm{~mm}$ in shell length) (Kakino 1998). $\bullet$, area from Ushigome to Kaneda ; $\bigcirc$, near part of Obitsu River mouth.

外の領域では, 肥満度は沖合ほど高く, 丸形指数は沖合ほ ど小さくなることがわかる。これらの分布特性から，沖合 の方がアサリの成長に適していることが明らかである。

流速とアサリ肥満度の関係を Fig. 8 に, 流速と丸形指数 との関係を Fig. 9に示す. 肥満度については, Fig. 6 で示 した調査点毎に平均值を上回った頻度（回数）の1回につ き $25 \%$ の数值（調査回数は 4 回であるから $0,25,50,75$, $100 \%$ の 5 段階）を与え，百分率 (\%) で示した。アサリの 成長を左右するのは流速だけではなく，地盤高など別の因 子が関与する（增殖場造成計画指針編集委員会 1997）。特 に，漁場の沖合側になるほど，流速が速いだけではなく， 餌料量が多く（杮野 1998）, 水温, 塩分の変動が少ない (柿野ら 1995）などのアサリの成長に好適な条件が多くな
る。これらの影響を出来るだけ除くために，潮下带（D.L.0 $\mathrm{m}$ 以深), 干潟上の D.L.0 40 cm, D.L. $40 \mathrm{~cm}$ 以浅, の 3 区 域に分けて相関関係を調べた。

流速と肥満度との間には正の相関 $(r=0.59 \sim 0.67)$ が，流 速と丸形指数の間には負の相関 $(r=-0.80 \sim-0.48)$ がみら れた。流速と肥満度拈よび流速と丸形指数の関係ともに, 区域に分けて調べた各相関関係よりも全区域を一括して調 ベた相関関係の方が相関係数が高くなった。これは, 沖合 い側では流れが速いだけではなく，成長に関わる他の正の 要因も相乗的に作用したためであろうと推定される。また， 潮下带 (D.L. $0 \mathrm{~m}$ 以深) に打ける流速と丸形指数の相関関 倸 $(r=-0.48)$ が低かったが, 澪があると餌料を多量に含ん だ沖合水が流入しゃすく, 成長が早くなる可能性が高いの 


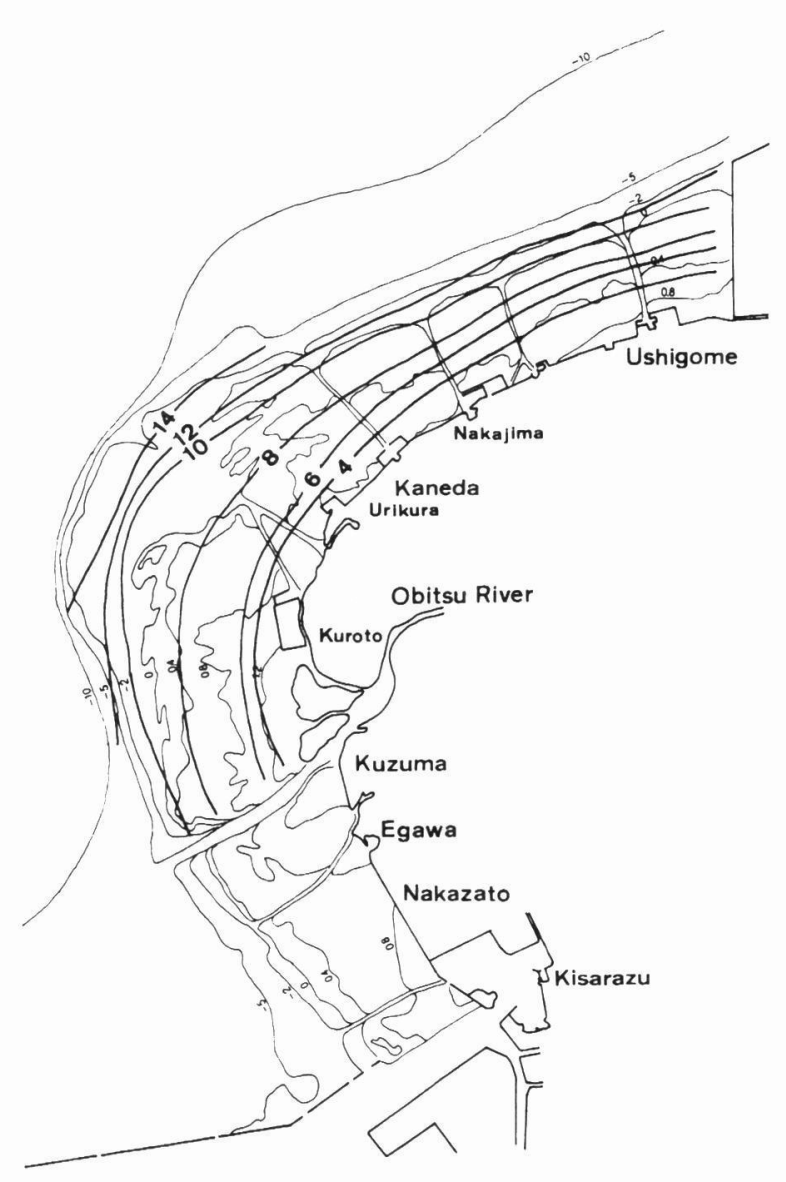

Fig. 5. Distribution of tidal current velocity $(\mathrm{cm} / \mathrm{s})$ calculated by simulation. Velocities shown are means of the maximum velocities during ebb and flood tides in summer (Kakino 1996a).

で, 澪近傍 4 地点 (+の地点) の值を除くと, $\mathrm{Y}=$ $-0.389 X+48.6$ となり，相関係数 $(r=-0.698)$ が高くなっ た。これらのことから，流速は成長に関与することが明ら かである。肥満度よりも丸形指数の方が高い相関を示すこ とについては，丸形指数の方が長期的な成長に関わるアサ リの状況を示すためであると考えられる。

\section{波とアサリの生息密度との関係}

アサリは，元来静穏な場所に生息する二枚具である(例 えば，倉茂 1943; 山口県 1980 など)。東京湾では富津岬上 り北側のいわゆる東京内湾が主たる生息場所であるが(千 葉県 1983)，内湾であっても詳細にみると，波の影響が大 きいアサリ漁場の沖合側（砕波带の領域）で密度の減少 （柿野・鳥羽 1990）や成長の低下（柿野 1995）がみられ る. 1989 年の冬季に盤洲干潟ではアサリの大量へい死が発 生し（柿野ら 1992），冬季に大量へい死がみられなかった 時も密度の減少がみられる（柿野 1996b）。この冬季のアサ リ密度の減少は, 冬季の干潟に設置されるのり養殖支柱柵 数が近年減少したため，干潟に入射する波が強くなってい ることが大きな要因の一つであると推定されている（柿野

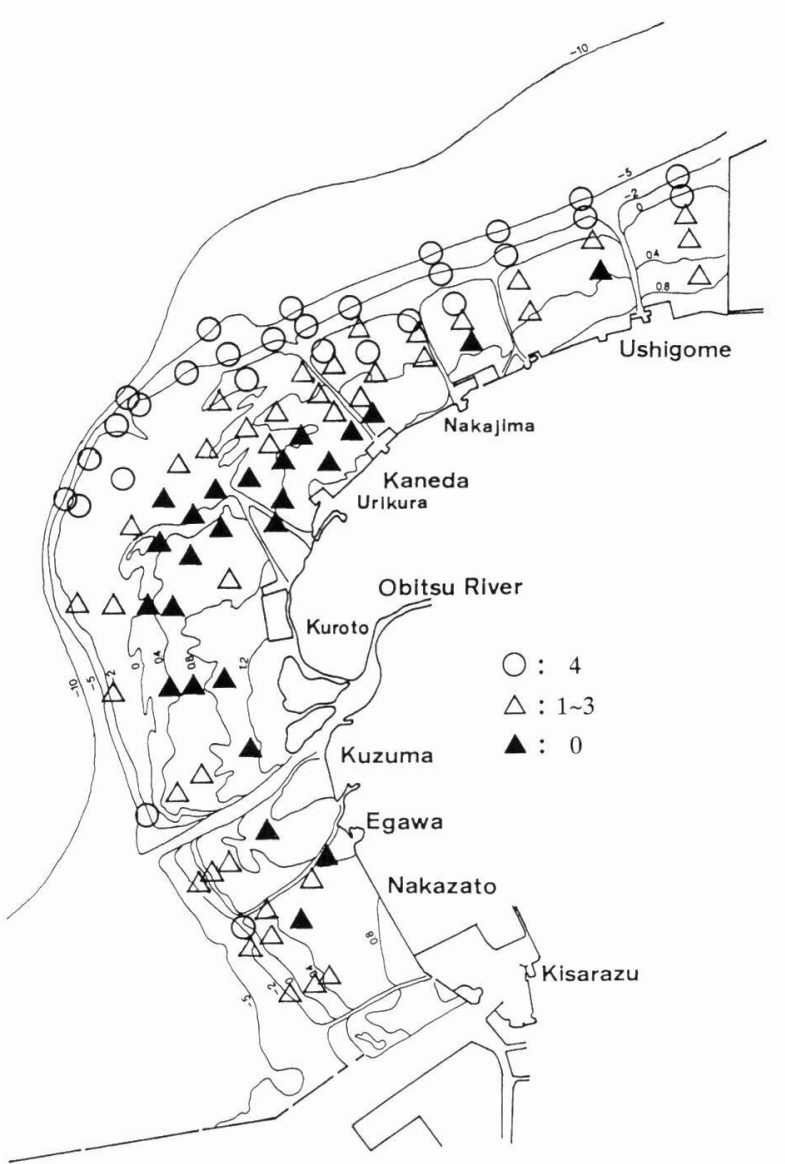

Fig. 6. Distribution of condition factor values in Ruditapes philippinarum (about $30 \mathrm{~mm}$ in shell length). Condition factor was investigated in May and October of both 1984 and 1985. Symbols show the number of observations in which a value exceeded mean estimated at each observation $(n=4)$ (Kakino 2000a).

ら 1995; 柿野 1998).

そこで, 冬季を中心として1994 年秋季から 1995 年春季 (約 6 力月間) にかけて, 干潟上 6 地点に平均殸長 $28 \mathrm{~mm}$ のラッカースプレーで着色した生きているアサリ抄よびホ ルマリンで固定したアサリを 1 地点当たり各々 50 個体ず つ埋めた，各地点の試験区に残っている個体数を短期間 （7〜12 日間）経過後に調べる調查（短期間調查， 5 回実 施）と，長期間（23～53 日）経過後に調べる調査（長期間 調査, 4 回実施）を，交互に合計 9 回行った。同時に，砂 面計を用いて同じ 6 地点で全期間にわたって海底面の変動 を測定した。また，波高計を用いて前記 6 地点の中の 3 地 点で 45 日間の波高観測を行った。これらの結果に基づき, 短期間調査に扔けるアサリの生息密度と海底面の変動㧍よ びシールズ数との関倸を調べた（柿野 2000a; Kakino 2000b).

ここで用いているシールズ数 $\left(\bar{\psi}_{\mathrm{m}}\right)$ は無次元の底面せん 断応力であり，砂粒子を移動させようとする力と止まらせ ようとする力の比であらわされる。ここでは波単独の場合 を扱っており，以下の式で計算される。 


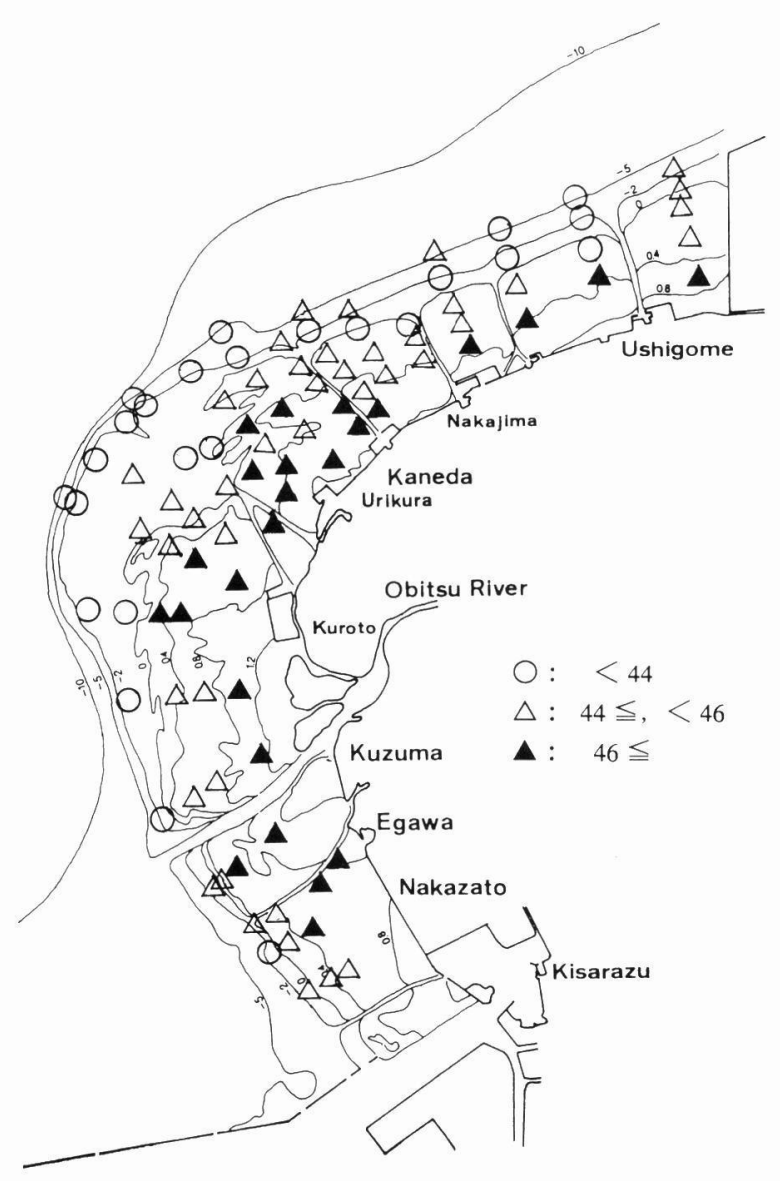

Fig. 7. Distribution of shell sharpness index in valves of Ruditapes philippinarum (about $30 \mathrm{~mm}$ in shell length). The sharpness index was investigated in May and October of both 1984 and 1985. Symbols show means of four investigations (Kakino 2000a).

$$
\begin{gathered}
\bar{\psi}_{\mathrm{m}}=1 / 2 \cdot \psi_{\mathrm{m}} \\
\bar{\psi}_{\mathrm{m}}=u *^{2} /\{(s-1) g D\} \\
u *=u_{b \mathrm{~m}} \sqrt{0.5 f_{\mathrm{w}}}
\end{gathered}
$$

ここで, $u *$ は底面摩擦速度, $u_{\mathrm{b} \mathrm{m}}$ は底面における水粒子流 速の振幅, $f_{\mathrm{w}}$ は Jonssonの摩擦係数, $s$ は砂粒子の比重, $g$ は重力の加速度, $D$ は砂粒子の中央粒径で定義され, 值が 大きいほど，海底砂が波によって動かされやすいことを意 味している。

なお，シールズ数を算出するためには，波（波高，周期） のデータが必要であるが，波高計による観測は45日間行っ ただけなので，残りの期間については，以下のようにして 波高，周期を推定した。即ち，まず，波高計を設置した 3 地点の各短期間調査において砂面計で侵食の最大值が測定 されたときの水深, 風向, 風速を求めた。次に, 各地点 (3 点) において, 同じ水深 $( \pm 20 \mathrm{~cm}$ の範囲) および同風 向の時の実測值による風と波高および風と周期の一次相関 式を作成し, この式に前記の風速の值を代入して, 波高, 周期を求めた（杮野 2000a; Kakino 2000b）.
また，砂面計による測定記録（測定は 1 時間に 1 回）を みると，波高が大きい時に急激な侵食がみられたが，これ は砂面計のセンサーが組み込まれているポールによる局所 洗掘である可能性が高いので, 解析から除外し, 局所洗掘 が始まる前と後の海底面の変化を（堆積の場合も含めて） 短時間侵食と定義した。

7〜12 日の短期間調査の期間内に砂面計で測定された短 時間侵食の最大值（侵食がなからた場合は堆積の最大值を 表示）と以下に記す試験アサリの定位率,

$$
\text { 定位率= } \frac{\begin{array}{c}
\text { 試験終了時に試験区画に } \\
\text { 止まっていた個体数 }
\end{array}}{\begin{array}{c}
\text { 試験開始時に試験区画に } \\
\text { 埋めた個体数 }
\end{array}} \times 100
$$

の関係をFig. 10 に示す。なお，一つの侵食深さに対して 複数の定位率の測定值が得られた場合は, 図中にその出現 回数を○の大きさで示した。同図から海底面の侵食深さが $-2 \mathrm{~cm}$ を越えると, 移動させられるアサリ個体数が多くな ることがわかる。その際に，眓中に平均值を波線で示した ホルマリン固定のアサリは, 海底砂中で垂直移動しない. ゆえに, その場から掘り出されて移動させられる個体数は, 実線で示した生きているアサリよりも多くなる。即ち定位 率が低くなる傾向を示す。海底面の変動と波高計で実測し た波のデータ，および海底砂の粒径等から算出したシール ズ数との関係を Fig. 11 に示す。海底面の变動とシールズ 数との間には一次式などで表される明瞭な相関関係はみら れないが, シールズ数 0.12 以下では海底面はほとんど変化 せず，0.12〜0.16ではやや堆積傾问，そして 0.20 を越える と侵食傾向になる。シールズ数とアサリ定位率との関係を Fig. 12 に示す。眓中の大きい表示シンボルは波高と周期の 実測值，小さい表示シンボルは推定值から算出した值であ る.シールズ数が 0.2 を越えるとアサリの定位率が急激に 低下寸る。これらの結果から，波高が大きくなることに よってシールズ数が増大し, 海底面の侵食が深くなると, その場からアサリが掘り出され, 定位率が低下することが わかる。

掘り出されたアサリは波によって運ばれる距離が短く, アサリにとって好適な生息条件の場所に止まるのであ机ば， 再びその場所で砂中に潜って生存すると考えられる。しか し, 岸側の高地盤域や沖合の潮下带あるいは澪（航路）の 深みまで運ばれると, 高地盤域では長時間の干出による餌 料不足や夏季の高水温, 潮下带や澪の深みでは生存限界を 超える過剩の泥分や夏季の貧酸素水などの厳しい生息条件 のためにへい死しやすくなると推定される。盤洲下潟で 1994 年秋季から 1995 年春季まで約 6 力月間に砂面計で測 定された $-2 \mathrm{~cm}$ 以上の浸食は，支柱柵沖側の 2 地点のうち 1 地点で 10 回，他の 1 地点で 6 回発生しているので (柿野 2000a)，大きな波浪の干潟（アサリ漁場）への入射 
$\operatorname{Tota} 1(D L,-5 m \sim+1.0 m), \quad Y=11.04 X-52.5(r=0.804)$

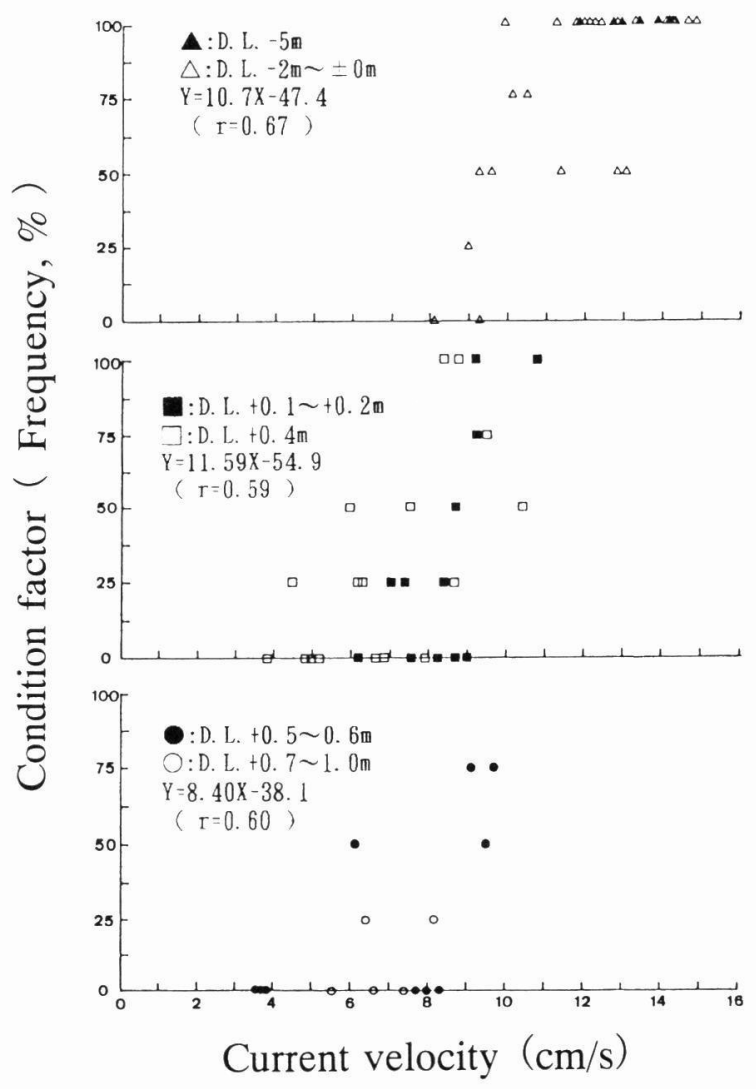

Fig. 8. Relationships between tidal current velocity (see Fig. 5) and condition factor of Ruditapes philippinarum at three tidal levels. Frequency $(\%)$ was estimated by the number of observation in which a value exceeded a mean estimated at each observation $(n=4 ; 0,0 \% ; 1$, $25 \% ; 2,50 \% ; 3,75 \% ; 4,100 \%$ ) (Kakino 1996a).

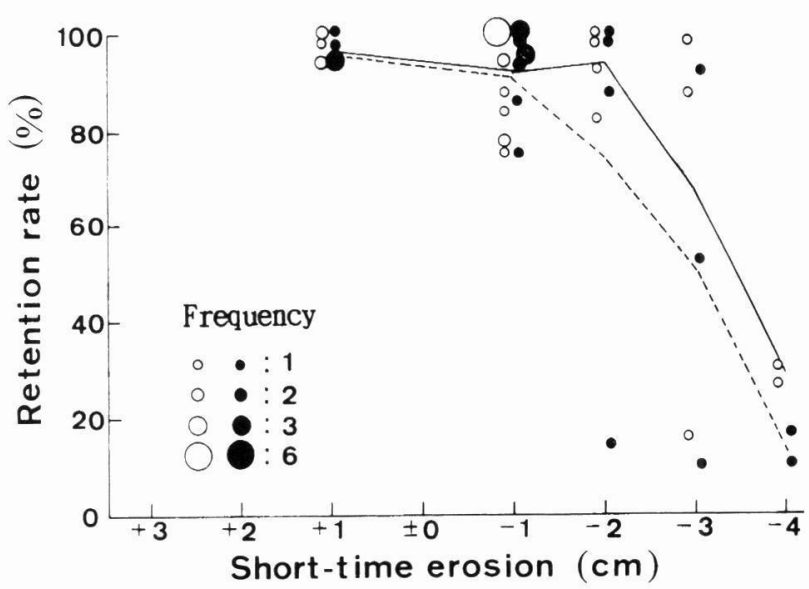

Fig. 10. Relationship between maximum short-time erosion during an observation period ( $7-12$ days) and retention rate of Ruditapes philippinarum (Kakino 2000b). $\bigcirc$, live clam;

- formalin-fixed clam.

による1回当たりのアサリの移動はそれほど大きくなくて も，何回も反復することによって，漁場に打けるアサリ個 体群密度の減少は無視出来ない大きさになると考えられる。

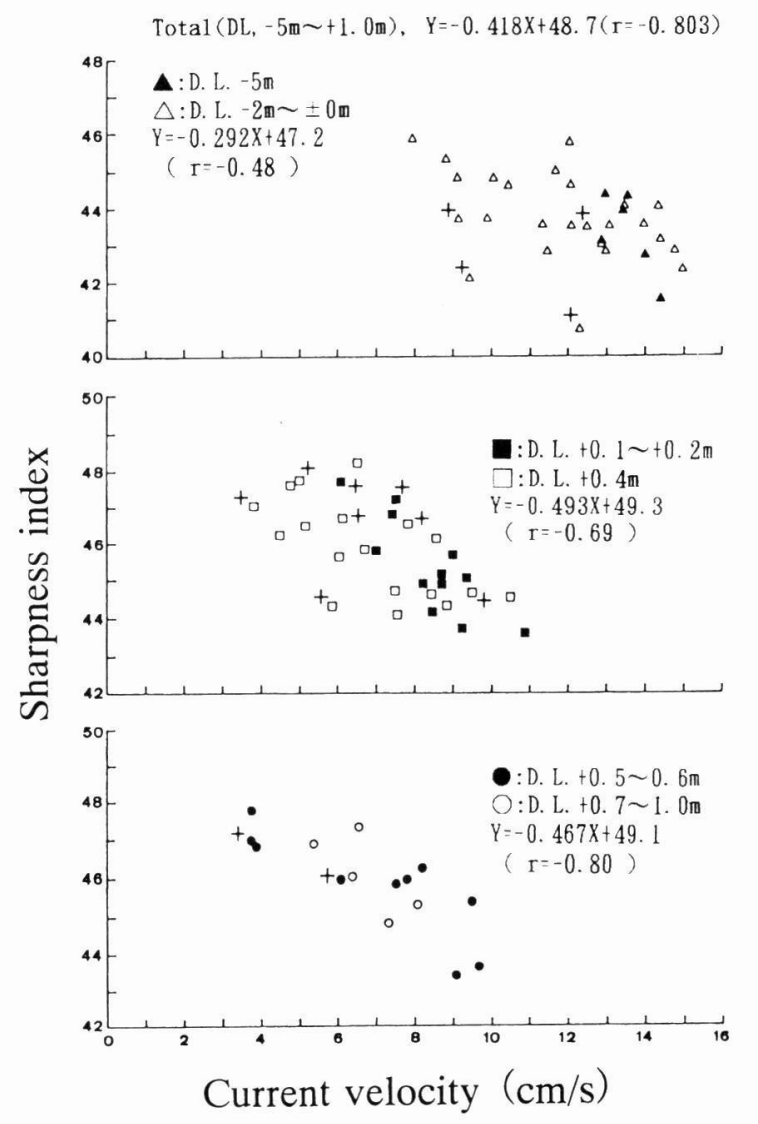

Fig. 9. Relationships between tidal current velocity and sharpness index of Ruditapes philippinarum at three tidal levels. +: sampling sites in the vicinity of boat channels (Kakino 1996a).

盤洲干潟に打けるのり養殖施設の 1969 年, 1974 年, 1984 年，1994 年の配置を Fig. 13 に示す。1 1974 年以降には 沖合にベ夕流し施設（浮き流し施設）が，干潟上に支柱柵 施設が設置されている。 20 年後の 1994 年には両施設とも に減少しているが，支柱柵の減少の方が大きく, 1970 年代 まで干潟の岸に平行に 4 列以上設置されていた支柱柵が, 現在は 2 列前後に減少している。ベタ流し施設は沖合のお およそ水深 5 10m の場所に設置され，波に対する主要な 抵抗体となるノリ網は波に追従して海表面を上下動する構 造となっているので, アサリ漁場（大潮満潮時で水深 $2 \mathrm{~m}$ 以浅) に直接設置される支柱柵による波高減衰と比較すれ ば影響は小さいと想定される。ここでは支柱柵による波高 減衰について，以下に記す水理模型実験の結果を用いて検 討する.

水理模型実験の結果 (Fig. 14) では，以下に示す波高減衰 率 $\left(\lambda_{\mathrm{H}}\right)$,

$$
\begin{aligned}
\lambda_{\mathrm{H}}=1-\mathrm{H}_{1} / \mathrm{H}_{0} & \\
& \left(\mathrm{H}_{0} \text { は支柱柵沖側の波高, } \mathrm{H}_{1}\right. \text { は支柱柵岸側の波高) }
\end{aligned}
$$

は波形勾配 $\left(\mathrm{H}_{0} / \mathrm{L}_{0}\right)\left(\mathrm{L}_{0}\right.$ は支柱柵沖側の波長）と相関関係 


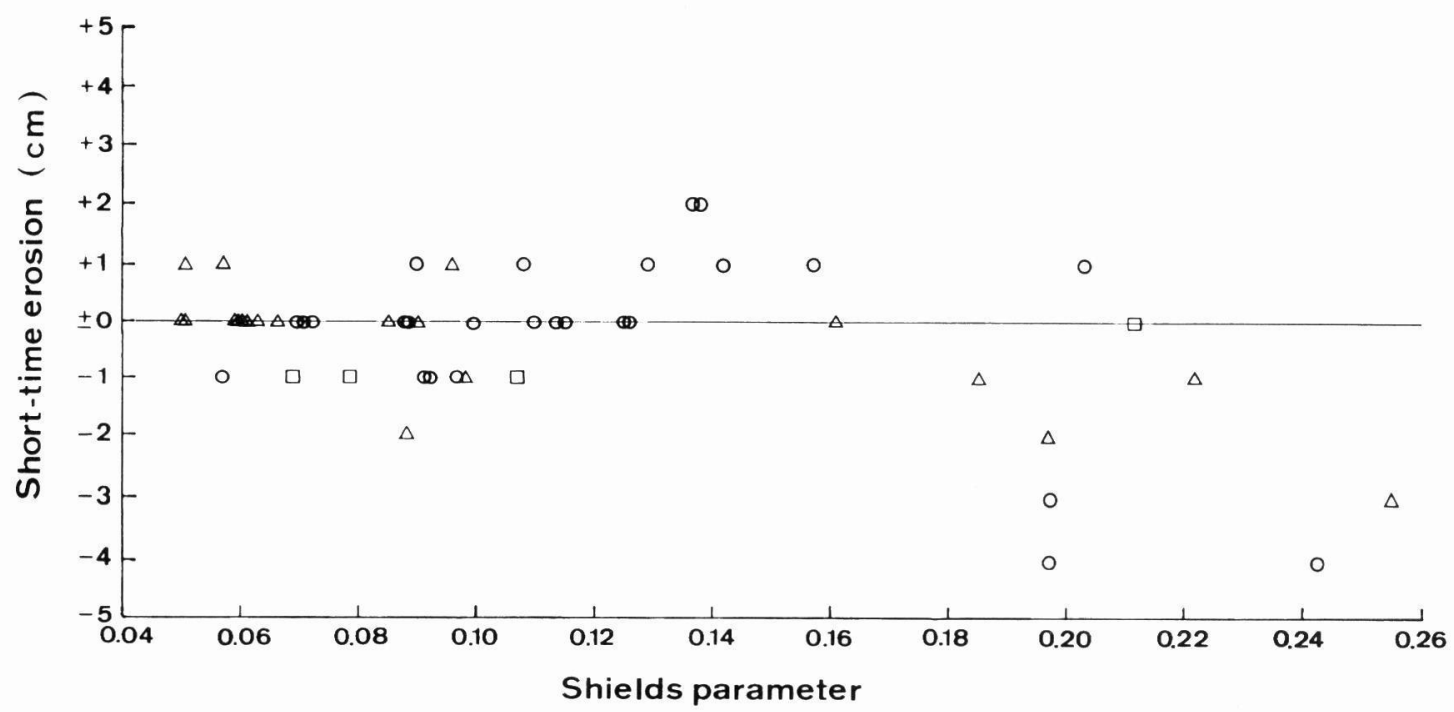

Fig. 11. Relationship between the Shields parameter and the short-time erosion (Kakino 2000b). $\bigcirc, \triangle$, observation points on the off-shore side of the laver culture structures; $\square$, observation points on the shore side of the laver culture structures.

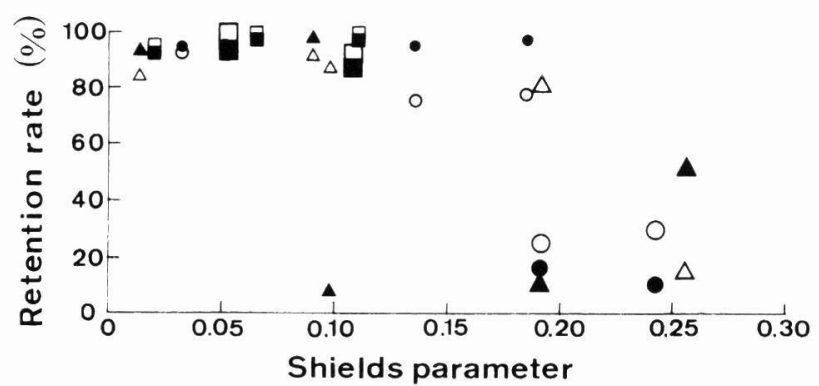

Fig. 12. Relationship between the retention rate of Ruditapes philippinarum and the Shields parameter during the observation periods (712 days). Large symbols and small symbols show the measured data and the estimated data, and white symbols and black symbols show the live clams and the formalin-fixed clams, respectively (Kakino 2000b). $\bigcirc, \Delta$, $\boldsymbol{-}, \boldsymbol{\Lambda}$, observation points on the off-shore side of the laver culture structures; $\square, \mathbf{\square}$, observation points on the shore side of the laver culture structures.

を持ち，「のり網を取りつける支柱」のみから「支柱 + の り網 (固定式) + の葉体」まで 6 シリーズの実験では, 「支柱 + のり網 +のり葉体」が最も大きな波高減衰率を示 した。「支柱 + のり網 $($ 浮動式 $)+の り$ 葉体」では,

$$
\lambda_{\mathrm{H}}=2.36\left(\mathrm{H}_{0} / \mathrm{L}_{0}\right)+0.060 \quad(r=0.893)
$$

「支柱 + のり網 $($ 固定式 $)+の り$ 葉体」では,

$$
\lambda_{\mathrm{H}}=2.19\left(\mathrm{H}_{0} / \mathrm{L}_{0}\right)+0.140 \quad(r=0.929)
$$

の実験式が得られた。この実験式によって算出した波高減 衰率は現地観測結果よりも小さい值を示している（柿野 2000a)。しかし，比較検討はできると考え，1970 年代以前 と現在の波高変化をみるため, 支柱柵を 4 列から 2 列に減 少させた場合の，波高減衰率の変化を前記の実験式を用い て試算した。その結果, 波形勾配は現地観測結果では
$0.01 \sim 0.02$ の出現頻度が最も高いので，波形勾配 0.01 の き浮動式（のり網は支柱に通してあるリング状のフロート に連結されているので, 波に追従して海表面近くを上下動 する）では波高減衰率が 0.36 から 0.16 , 固定式(のり 網は支柱に固定されて動かない) で 0.50 から 0.30 人, そ れぞれ減少する。波形勾配 0.02 のとき浮動式で 0.35 から 0.20 人, 固定式で 0.54 から 0.33 , それぞれ減少する. 2 列と 4 列のときの波高減水率をそれぞれ $\lambda_{2}, \lambda_{4}$ とすると,

$$
\text { 波高増加率 }=\left(1-\lambda_{2}\right) /\left(1-\lambda_{4}\right)
$$

で計算されるので, 波形勾配 0.01 のとき浮動式では波高増 加率が 1.2 倍に, 固定式では 1.4 倍に, また, 波形勾配 0.02 のとき浮動式では 1.2 倍に, 固定式では 1.5 倍に，そ れぞれ増加する。底面摩擦速度は摩擦係数が一定とすれ ば，波高に比例し，シールズ数は 2 乗に比例するから， シールズ数は 1.4 倍から 2.3 倍増大することになる.

これらの解析結果掞よび当該地先における45日間の現 地観測結果では，最も沖合に位置する支柱柵に人射する波 から算出したシールズ数の最大值が 0.25 程度（柿野 2000a） であったことを勘案すると，支柱柵が 4 列以上設置されて いた当時は，干潟の広い範囲でアサリが移動し始める限界 シールズ数 0.2 以下になっていたと推定される。これらの 静穏域は, 支柱柵の減少とともに，当初は徐々に，近年ほ ど急激に，減少したと推定される。

以上のように，支柱柵の近年の大きな減少は，干潟の波 高增大をもたらすことによって，アサリの冬季の生息密度 が減少し，ひいては，近年のアサリ生産量を低下させる大 きな要因になっている可能性が高いと推定される.

本稿の内容は, 第 15 回日本ベントス学会シンポジウム 「今，アサリが危ない」における口頭発表を補強して記述 したものである。内容の詳細については，原著を参照願い 
969

1974
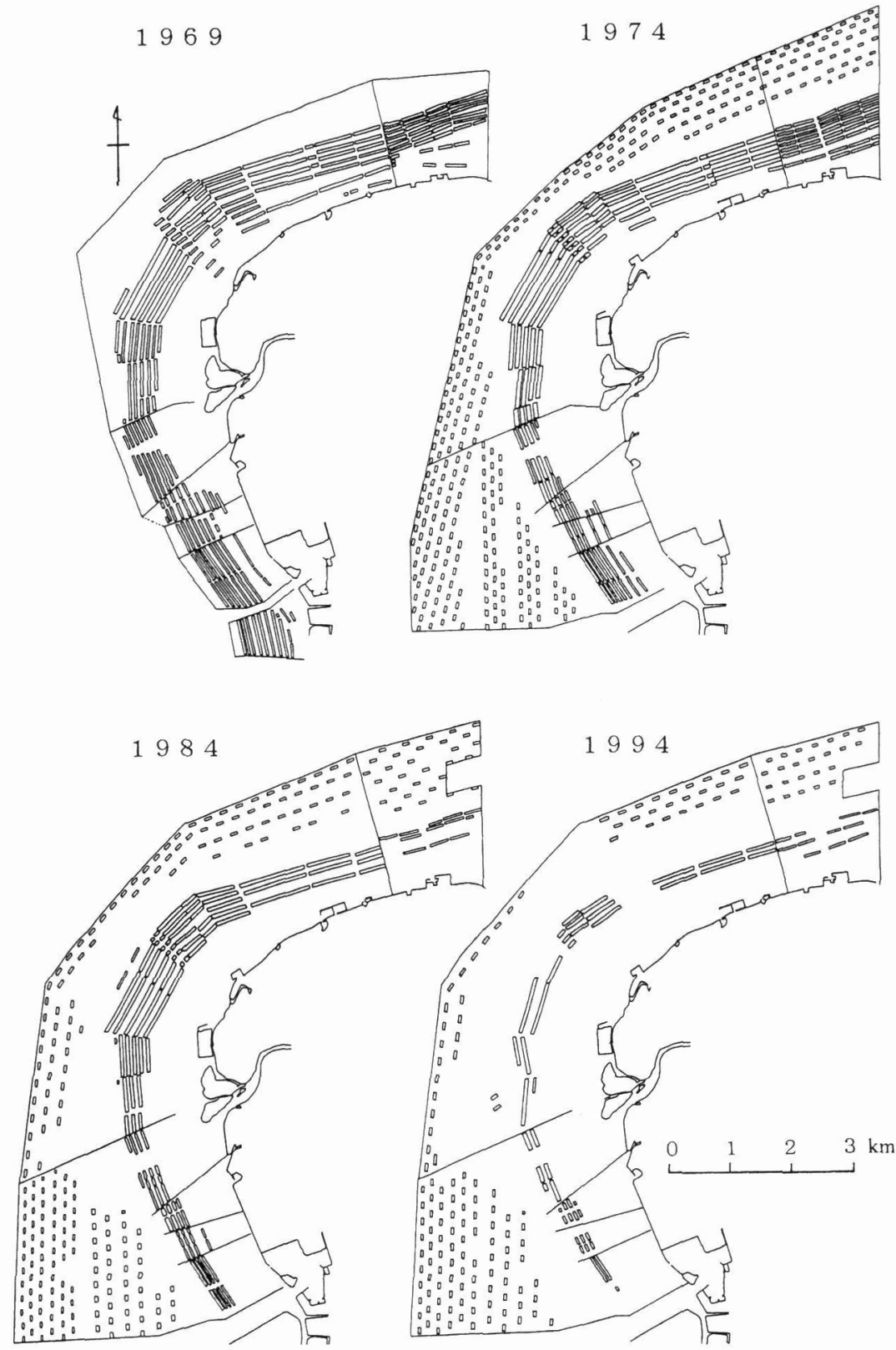

Fig. 13. Changes of distribution of laver culture structures in the Kisarazu area. Small rectangles in off shore represent floating-type structure, while large rectangles close to shore represent prop-type structure (Kakino 2000a).

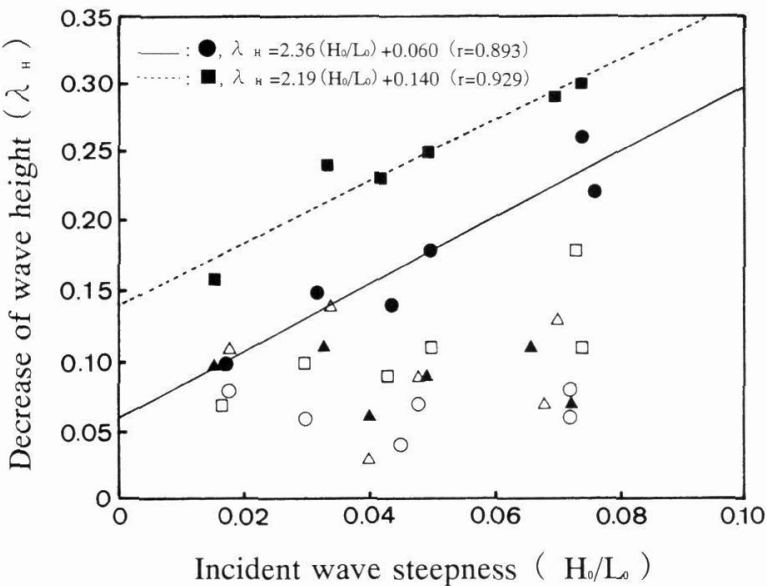

Fig. 14. Relationship between the incident wave steepness $\left(\mathrm{H}_{0} / \mathrm{L}_{0}\right)$ and decrease in wave height $\left(\lambda_{H}\right)$ in a hydraulic model test of prop-type laver culture structures. Nets pitched between stakes were either floating type or fixed type (Kakino 2000a). O, stake; $\triangle$, stake+laver culture net (floating); $\square$, stake + laver culture net (thick fiber, floating); $\bullet$, stake + laver culture net (floating)+laver leaf; $\boldsymbol{\Lambda}$, stake+laver culture net (fixed); $\mathbf{\square}$, stake + laver culture net (fixed) + laver leaf. 
たい。シンポジウムの内容である「今，アサリが危ない」 ことについては，多方面から要因を検討すべきであり，こ

こで紹介した物理環境の変化のみによって説明できないか もしれないが, 物理環境要因は, 漁場によってはアサリの 資源量に大きな影響を与えていることは明らかである。末 尾ながら英語部分を校閲していただいた Mark Grygier 博士 に深く感謝申し上げる.

\section{引用文 献}

千葉県 1983. 昭和 55 57 年度 ·海域総合開発調査事業報告書 (内房海域). pp. 99-100.

Cragg, S. M. 1980. Swimming behaviour of the larvae of Pecten maximus (L.) (Bivalvia). Journal of the marine biological Association of the United Kingdom, 60: 551-564.

井上 泰・山田曙美 1954。アサリ二形の成長並びに形態の变化に ついて (浅海增殖に関する調査研究)。山口内海水試調查研究 業績, 3: 1-11.

柿野 純 1988. 東京湾, 千葉県沿岸におけるアサリ・バカガイの 生息と環境. 水産海洋研究会報, 52: 45-47.

杮野 純 1995. 丸型指数を指標とした篭試験によるアサリの成長 と生残の特性. 日本水産学会誌，62: 376-383.

柿野 純 1996a. 東京湾盤洲干潟におけるアサリの成長と流れと の関倸。千葉県水産試験場研究報告, 54: 7-10.

杮野 純 1996b. アサリ漁業の動向と近年の調査結果. 水産海洋 研究, 60: 265-268.

柿野 純 1998. 干潟漁場. 沿岸の環境圈 (平野敏行監修)。東京, フジテクノシステム, pp. 378-391.

杮野 純 2000a. 東京湾盤洲干潟におけるアサリの減耗に及ばす 波浪の影響に関する研究. 東京水産大学学位論文, $140 \mathrm{pp}$.

Kakino, J. 2000b. Dispersal of Japanese littleneck clam Ruditapes philip- pinarum (Adams and Leeve) in lelation to changes of bottom level due to wave action on Banzu tidal flats, Tokyo Bay. Fisheries Engineering, 37: 115-128.

杮野純・古畑和哉・長谷研一1995. 東京湾盤洲干潟に扔ける冬 季のアサリへい死要因について。水産工学, 32: 23-32.

柿野 純. 中四喜三郎·西沢 正·田口浩一 1991a. 東京湾盤洲 地先におけるアサリ稚貝の発生と渦度との関係. 水産工学, 28 : $43-50$.

杮野 純·中田喜三郎·西沢 正·田口浩 - 1991b。東京湾盤洲 地先に拀けるアサリの生息と波浪との関係。水産工学, 28: 5155.

柿野 純・鳥羽光晴 1990.千葉北部地区におけるアサリ資源の特 性について。千葉影水産試験場研究報告, 48: 59-71.

杮野 純. 鳥羽光晴 - 兼子昭犬. 深山義文 1992. 東京湾木更津 地先における冬季のアサリへい死の特徵. 千葉県水産試験場研 究報告, 50: 21-30.

倉茂英次郎 1943。アサリの適正条件としての地盤並びに土質の 変動. 日本海洋学会誌, 3: 94-117.

西沢正・柿野 純 - 中田喜三郎 - 田口浩一 1992. 東京湾盤洲 干潟におけるアサリの成長と減粍。水産工学, 29: 61-68.

崔 相・大島泰雄 1958 . 成長の抑制されたアサリの移植による成 長と款形の変化について. 日本水産学会誌, 24: 616-619.

鳥羽光晴・㭪野 純 1992.アサリの成育環境と種苗放流, 東京湾 千葉県木更津地先の干潟漁場での調査事例。平成 5 年度水産工 学研究推進全国会議講演集, 水産工学研究所, pp. 25-30.

杜多哲 1991。浅海域での地形・構造物により造成される循環流 と生物分布. 流れと生物と (河合英夫編). 京都, 京都大学出 版会, pp. 191-215.

山口県 1980 . 大規模増殖場造成事業調査総合報告書，山口·大 海湾地区，一アサリ一。水㦃广。

増殖場造成計画指針編集委員会（編）1997。増殖場造成計画指針 一ヒラメ・アサリ編一 (平成 8 年度版)。(社) 全国沿岸漁業振 興開発協会, 東京, $294 \mathrm{pp}$. 